\title{
"This Is, Indeed, the Heart of the Matter"
}

BY JAMES F. GOVAN

$\mathrm{U}$

NDERGRADUATE EDUCATION in this country today faces two serious problems, either one of which singly would pose difficulties of almost unmanageable proportions. On the one hand, it must shortly provide for great increases in enrollments, and on the other, it must improve its quality. This dual challenge has already produced voluminous discussion in academic circles, and bids fair to be the center of educational controversy for an entire generation.

Usually these two problems are discussed separately, for few proposals comfortably combine solutions to both. There is a real danger that the pressure of increasing enrollments will demand accommodation at the expense of any effort to raise standards. As Robert Downs has warned, the tendency may well be to take the line of least resistance, to dilute instruction, and to resort to methods of mass communication. ${ }^{1}$ Certainly much of the discussion thus far justifies these forebodings. Too often it has centered around the idea of extending the range of the instructor's voice through television. This plainly would accommodate larger numbers of students. That it would raise the quality of instruction is much less certain.

Unfortunately, our present instructional methods lead naturally to this line of reasoning. For these proposals merely assume the perpetuation of the lecture system in its present form and ubiquitousness. This is not the time or place to go extensively into the virtues and vices of that system of instruction. But whatever its deficiencies in the past, it is clear that there are more to come. For one thing, the burden, already unwieldy, of providing new and qualified 1 Robert
Libraries," Downs, “Crisis in Our University
Mr. Govan became Librarian of Trinity University, San Antonio, Texas, in 1961. He took his doctorate in English history in 1960.

faculty promises to become crushing. Moreover, as the demand for faculty mounts in relation to the supply, it is inevitable that the larger and richer institutions will draw on the smaller and poorer ones. The New Republic, in a recent editorial discussing this inequity and its results, aptly labeled the victims of these raids on faculty personnel "the intellectual slums" of the future. ${ }^{2}$ To a certain extent, this attrition of small institutions has already begun, and no proposal leaving the lecture system unchanged will solve it.

What, then, is to be done? More independent study by undergraduates seems inevitable. The question is what form it is to take. A substitution of the printed word for the spoken word, of reading by the student for at least some of the lectures on which we rely today, seems to offer the best solution. A number of librarians have already pointed out in the journals of the profession that a technological invention of the fifteenth century, the printed book, still outstrips all others when it comes to imparting information and developing critical judgment. ${ }^{3}$ One of the great deficiencies of our instruction in the past has been our failure to assign a more prominent role to the book, and we now have an opportunity, perhaps, to expand that role in higher education.

2 "Intellectual Slums," The New Republic, March $27,1961,3$.

3 See, for example, Frederick Wagman, "Library Requirements of the Modern College," The Library Quarterly, XXXI (1961), 38; and Wyman W. Parker, "College Library Standards and the Future," CRL" XIX (1958), 359 . 
Numerous experiments with instruction are going on in our colleges and universities, and almost all of them require more independent reading by students. In fact, this kind of course has long been familiar to many campuses in the country. Over the past twenty-five years, the tendency has steadily been in the direction of laying less emphasis on a single textbook and relying more on the library collection through reserve lists, outside readings, and the like. Even in the most provincial institutions, individual instructors give reading courses from time to time. And it is the common practice to require large amounts of independent reading of advanced undergraduates enrolled in courses with graduate students.

The foundation on which to build, then, already exists. The difficulty is that it is merely a foundation. Only our more prominent universities and colleges offer reading courses regularly, and even these institutions normally limit them to honors courses. Yet is there any truly insurmountable obstacle to providing courses for all students on an advanced undergraduate level in which independent reading largely replaces classroom lectures? Why could not reading courses become the normal pattern for junior and senior work as the lecture course has been up to this time?

Under such a program a student, having passed his basic curriculum, would have to attend only one lecture a week and could spend in reading the time he now devotes to preparing for and attending two or more additional lectures. He would receive an annotated bibliography on the subject under study as well as more specialized bibliographies for each week's lecture. Within the scope of these fairly exhaustive reading lists, he could make his own selections and follow his own interests. If the instructor desired, he could arrange periodic consultations with his students, or, if circumstances permitted, assign them to graduate assistants for consultations. He could also require a research paper or not, as he saw fit (although to tie the independent reading entirely to this paper, as some instructors do now, would defeat the purpose of the course). Examinations of the conventional type, but framed to include a variety of individual interests, could still be given.

The above is merely a suggestive outline. Local needs and circumstances would necessarily determine the details of these courses. If it seemed desirable to introduce them as honors courses, for example, they could later be expanded to include all advanced courses, as the student body became accustomed to them. And their adoption, so far from prompting the neglect or abandonment of other forms of instruction, might easily come hand-in-hand with these alternatives. It is quite possible, for instance, that televised lectures by distinguished authorities in a subject, when supported by extensive reading by the students, could greatly enhance the value of the course. But the fundamental and essential point is that books and students come in closer and more constant touch, and that lectures occupy less time for both faculty and students.

The advantages of this program seem to me to outweigh the disadvantages decisively. There is no substitute for the learning process a student alone with a book experiences. It can be argued that this self-education is the only real education. It seems, in any event, an experience a student must know well if he is to continue to educate himself, as we hope he will, after he graduates. The crippling neglect of individual reading and independent judgments in American colleges and universities is familiar to anyone who has worked in an academic library in this country. The lengths to which students will go to avoid reading and forming their own opinions of what they have read is legendary. As Harvie Branscomb pointed out some twenty 
years ago in his classic Teaching With Books, the instruction that the vast majority of our undergraduates receives not only militates against independent thinking and critical judgment but positively encourages an unquestioning deference to authority. ${ }^{4}$ The kind of graduates this education often produces has long been deplored by all who are interested in an educated and informed citizenry. (And this instruction just might go further, incidentally, than the blandishments of television westerns and crime stories to explain the limited reading public in America today.)

It seems essential, consequently, that a "reading course", in the sense being used here, should preclude specific assignments as much as possible, leaving the student free to pursue his interest within the realm of a broad bibliography. Let him rid himself of the tie to one source on every subject he studies: the instructor, a textbook the instructor has selected, or a reserve list of specific outside readings compiled by the instructor. Let him instead follow his individual line of reading, come up against conflicts of ideas in what he reads, and resolve these into opinions of his own.

Lectures, textbooks, and reserve lists simply cannot provide a similar experience. They cannot possibly supply either the variety or the profundity that wide reading in the literature of a subject affords. Under present conditions, the lectures given in classrooms are generally catalogs of basic information which is available in any good encyclopedia and which the student might well acquire before coming to class. Were he to devote these hours to reading, he could easily spend them with the foremost authority in the field rather than with an overworked instructor whose teaching load may compel him to present a highly superficial and pedestrian treatment of the subject.

4 (Chicago: Association of American Colleges-ALA, $1940)$, pp. $62-63$.
It is to be expected that some instructors will resent this innovation, regarding it as unappreciative of their indispensable contribution to the student's progress. This is the very opposite of the true intent and desired result of this proposal. The reduction of the teacher's time in the classroom to one meeting a week, with whatever additional consultations he desires, should permit him not only to keep in touch with the class's progress but will also enable him to perform at maximal capacity at the time he is before his students. The shift of responsibility to the student implied in this program is as important for its benefits to the instructor as for its benefits to the student. The hope is that the time is in sight when a well-trained teacher can abandon the role of taskmaster and disciplinarian to devote his time to acting as guide and critic.

Here may be one of the most valuable rewards to come from a wide adoption of reading courses. The harassed lecturer, relieved of two out of every three of his present lectures, would have the opportunity to prepare a lecture in the true sense of the word. If he met only four classes a week, instead of twelve, say, it is conceivable he would have adequate time to present an interpretive study of the week's work, tying the reading together and stimulating his listeners to further thought on their own judgments of what they have read. Moreover, he could then keep both himself and his students more nearly abreast of recent research and ideas on the subject before them.

The use of good books, no less than the full engagement of the faculty's talents and training, will become imperative as the better scholars on the campus depart for larger and wealthier institutions. A book, it has been repeatedly said, is a permanent acquisition (relatively speaking), requiring no annual salary to retain it. The editorialist of The New Republic, by way of sug- 
gesting a plan of intellectual slum clearance, concluded that only libraries of adequate size and quality could compensate for the concentration of the better scholars at the larger universities, and provide the necessary "academic equalizer."5 It is another point made years earlier by Dr. Branscomb, but it is a point which cannot be made too often. ${ }^{6}$

A fundamental change in instruction like this inevitably brings problems in its train. First, there is the providing of books in sufficient quantity. Larger student bodies reading still more books will tax the main library of the campus to the point of collapse. But the extent and nature of this added strain would depend largely on the bibliography and, of course, the size of the classes involved. Liberal use of paperbacks can relieve much of the strain. Already many advanced courses are requiring students to buy several paperbacks instead of a textbook. And it may well be, as Wyman Parker has suggested, that the paperback will surpass microreproduction in its impact on American education. ${ }^{7}$

It seems clearly possible that regardless of the changes in our instructional methods, we may be forced to supplement our present library resources with something on the order of dormitory libraries-made up of paperbacks, perhaps-on a larger scale than we have done on most campuses up to this time. Lewis Branscomb recently suggested that more extensive dispersals of library collections than we have known up to this time will result from larger student bodies. The present trend towards undergraduate libraries in some of our larger universities, as Dr. Branscomb indicates, is a frank recognition of this need to make books more available to undergraduate readers. ${ }^{8}$

\footnotetext{
5 Op. cit., p. 4.

6 Op. cit., p. 4

7 Op. cit, p. 359.

8 Lewis" Branscomb, "Libraries in Larger Institutions of Higher Education," Library Trends, X (1961), 188 .
}

But once again, specific arrangements for the provision of books would necessarily follow the dictates of local circumstances. The British universities which have provided books to enable students to "read" for a degree over many generations have long experience in this matter. Undoubtedly they could teach us a lot about it -as could those American universities which have adopted similar programs-and possibly suggest to us some practicable equivalent to the British college and house library.

There will be objections, too, that the American undergraduate cannot stand so nourishing a diet of learning, that he needs more personal attention, guidance, and, above all, coercion to work. This argument still finds adherents despite the evidence against it produced by reading courses and honors programs in our own universities. But to go further, anyone who takes this position, it seems to me, must be prepared to argue that American students innately are inferior to students of other nationalities. For the program set forth here is the ncrmal pattern of instruction in many universities abroad and brings excellent results. I prefer to think that its difficulties in this country stem more from our students' lack of effort and familiarity with it than from any deficiency in their ability.

Oddly enough, this objection sometimes comes from one's colleagues on the faculty. Presumably everyone in academic life has heard the argument. It is a real tragedy that this inclination to keep our sights low has so infected some of the very men and women who are supposed to be engaged in stretching young minds. I recently heard of a movement initiated by certain members of one faculty to reduce the library from fifty thousand volumes to ten thousand volumes in order to prevent the students from being confused over which books they should select! Here, obviously, the one-eyed are leading the blind, and one 
may legitimately wonder whether personal attention from faculty members of this persuasion would be of any educational value.

Some students unquestionably will abuse the freedom from close supervision by faculty. But, then, some students manage to resist education successfully under present circumstances. To those who insist that students will not do the work with anything less than three class meetings a week, ${ }^{9}$ I submit that such recalcitrants are in for an unhappy time in the future under any program. The mere number of their classmates is not only going to throw them more on their own responsibility but will force more selective standards both for entering and for remaining in school. This is all to the good. We have come dangerously close at times to believing that higher education should and can be forced on a rebellious young adult. The time for a renunciation of this philosophy, where it exists, is past due.

There will be much wailing and gnashing of teeth, no doubt, from the students until they become accustomed to doing more of their own work. Their chief complaint will be that they do not have the time for the necessary reading. But this complaint, when it is valid, results more from a meager acquaintance with books than anything else. So few of our students know how to examine a book properly, how to read discriminately in it from preface to concluding chapter and extract the meat of it in the shortest period of time. This is a skill that comes easily with time and training. It is only reasonable to assume that a period of two or three years or more would be necessary before students become sufficiently acquainted with this new method of instruction to adapt themselves to it without genuine struggle. But after it is established that advanced courses re-

9 For an interesting discussion of this point, see John S. Dickhoff, "Teacher Go Home," The Saturday Review, July 15, 1961, p. 52-53. quire more reading than listening and that one's education is primarily one's own responsibility, the difficulties will no longer persist and the effect will be salutary.

There are heartening signs that the student of the next decade will have far better preparation for reading courses than students of the past decade had. With the intensification of instruction in our high schools, the entering freshman soon may have many of the basic skills he formerly acquired during his first two years of college. In addition, more and more colleges and universities are encouraging students to acclimate themselves to independent reading through summer and holiday reading lists. If this trend continues, reading courses on the advanced level will soon be entirely consistent with the educational experience the student has had up to that point.

Other issues aside, no other proposal for accommodating the increase in students holds out any hope for continued close supervision of the student. Bookmen should seize this opportunity to put books in their proper place in higher education. The task of proselyting for programs similar to the one outlined above will fall largely and rightly to librarians-and to book-minded teachers. We need now to turn from arguing our case before our own profession and to convince our colleagues on our own campuses. Most faculties have a number of members who are still woefully ignorant of the library's proper role in education. It is, unfortunately, an ignorance to which librarians themselves have inadvertently contributed by repeatedly stating that the library is comparable to the laboratory-an adjunct or a support to instruction. No more erroneous analogy was ever drawn. The library is no specially equipped area where principles and theories learned in a classroom are demonstrated. It is rather the repository of those principles and theories, the 
source to which the lecturer must go before he teaches. This is no adjunct, no support. This is, indeed, the heart of the matter.

Were this truth to become more pertinent to teaching generally, we might expect more assistance from faculty members in educating students in the use of the library-a burden which regularly alarms librarians. If each instructor took it upon himself, as well he might in a reading course, to bring his class to the library and acquaint them with it (as some do even now), the pressure on the library staff would greatly diminish.

There is no point, however, in pretending that this pressure and, with it, the teaching function of the library staff will not steadily grow. This, in my opinion, is inevitable in any case and is a challenge that librarians should welcome. Lately we have shown great concern over the status and prestige of our profession. Much of this problem arises from our stressing the techniques we have developed rather than our knowledge of books, the truly unique contribution we can make to scholarship. It is as scholars that we find acceptance in a community of scholars. There is overwhelming evidence that any librarian whose position obviously demands scholarly proficiency, or who, as an individual, contributes to the intellectual life of the institution rarely decries his status on the campus. What better opportunity, then, could be asked for than that the teaching function of the library grow and the librarian's knowledge of books come more prominently into play?

The time is fast approaching when our institutions of higher education will necessarily modify many traditional forms of instruction and re-examine their fundamental organization and structure. The details of these changes, as important as they are, should take second place in librarians' minds to the overriding value of this opportunity. We should now carry Harvie Branscomb's exhortation to teach with books to our administrations and faculties as never before, providing them at once with a possible solution to the problems of expanded enrollments and an avenue to a higher level of instruction.

\section{Price to Libraries ... .}

The owners and publishers of journals, medical and scientific books, perhaps because they have to deal with scholars in medicine, in science, and in teaching, have generally and rightly been considered to be above reproach. [But] recently several practices have arisen which suggest that a corruption of the profit motive has led to abuses which must be halted. . . . The first of these evils is the nasty little habit of charging libraries and institutions a fee of two or more times what an individual subscriber is charged for an essential though perhaps little read journal ... Libraries .. have to subscribe to a large variety of scientific journals. Canny profit-minded business managers see in this fixed market a chance to levy a tariff which scholars see only as an outrageous and scandalous corruption of ordinary business transactions. ... This practice gives an unscrupulous publisher a built-in windfall at the same time it frustrates librarians with a built-in headwind ... this form of discrimination puts an intolerable handicap upon the libraries. . . . Another [practice] used by some publishing houses... is to require prepayment for an unspecified number of issues of a particular journal. In a given year it may vary from one to three, four, or five issues. . . Libraries with fixed budgets cannot continue their essential function in an orderly way if publishers can levy taxes amounting to several times what the journal costs to a private person.-From an editorial by William B. Bean, Archives of Internal Medicine, CX, no. I (July 1962), 39-41. 